\title{
Feeding value of field beans (Vicia faba L. var. minor) with and without enzyme containing tannase, pectinase and xylanase activities for broilers
}

by Abdulla, J.M., Rose, S.P., Mackenzie, A.M. and Pirgozliev, V.R.

Copyright, Publisher and Additional Information: This is the author accepted manuscript. The final published version (version of record) is available online via Taylor \& Francis Please refer to any applicable terms of use of the publisher. 
1 Feeding value for chicks of field beans (Vicia faba L. var. minor) with and without enzyme containing tannase, pectinase and xylanase activities

3

Jalil Mahmwd Abdulla, ${ }^{\mathrm{a}, \mathrm{b}}$, Stephen Paul Rose ${ }^{\mathrm{a}, \mathrm{b}}$, Alexander Mackay Mackenzie ${ }^{\mathrm{a}}$, and Vasil Radoslavov Pirgozliev ${ }^{\mathrm{a}, \mathrm{b}}$

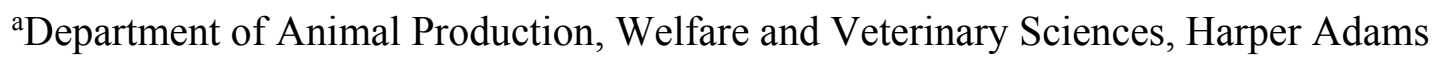
University, Newport, Shropshire, UK; ${ }^{b}$ National Institute of Poultry Husbandry, Harper Adams University, Newport, Shropshire, UK Corresponding author: V. Pirgozliev. E-mail: vpirgozliev@harper-adams.ac.uk T: +44 (0) 1952820280 F: +44 (0) 1952814783

\section{ABSTRACT}

Effects of field beans with various tannin content $(\mathrm{T})$ and exogenous enzyme containing tannase, pectinase and xylanase activities on N-corrected dietary apparent metabolisable energy (AMEn), coefficients of dry matter (DMR) and nitrogen (NR) retention, fat digestibility (FD), gastrointestinal tract (GIT) development, jejunal villus morphometry, ileal digesta viscosity and sialic acid (SA) were examined. Birds' growth performance and energy conversion ratio (ECR) were also measured. Birds were fed one of eight mash diets. A control diet was prepared that had major ingredients of $400.0 \mathrm{~g} / \mathrm{kg}$ wheat and $127.0 \mathrm{~g} / \mathrm{kg}$ soybean meal (SBM), and contained $221 \mathrm{~g} / \mathrm{kg} \mathrm{CP}$ and $12.83 \mathrm{MJ} / \mathrm{kg}$ metabolisable energy in agreement with breeder's recommendation. To reduce nutrient density the control diet also contained $119.1 \mathrm{~g} / \mathrm{kg}$ washed sand. Another three diets containing $300 \mathrm{~g} / \mathrm{kg}$ of each of three experimental field bean cultivar samples in replacement for soybean meal and sand were also mixed in order to have metabolisable energy and $\mathrm{CP}$ in a range similar to the control diet. Each diet was fed to nine pens with two Ross 308 male broilers following randomisation. 
Diets high in $\mathrm{T}$ had low $(\mathrm{P}<0.001) \mathrm{N}$-corrected apparent metabolisable energy (AMEn), ECR, DMR and NR. Feeding field beans increased $(\mathrm{P}<0.001)$ the weights of the pancreas and the proventriculus and gizzard (PG) of the birds. Supplementing diets with the enzyme mixture containing tannase, pectinase and xylanase activities improved $(\mathrm{P}<0.001)$ feed conversion efficiency, AMEn and all nutrient utilisation coefficient despite the $\mathrm{T}$ in diets. The enzyme mixture reduced ileal digesta viscosity $(\mathrm{P}<0.001)$ and the weight of the pancreas, the total GIT and the PG $(\mathrm{P}<0.05)$ of the birds. It can be concluded that the feeding value of field beans with different $\mathrm{T}$ contents may vary when fed to broilers. The enzyme mixture supplementation improved feeding value of diets for broilers. The beneficial effect of the addition of enzyme mixture containing tannase, pectinase and xylanase activities to poultry diets seems to be mediated through reduced ileal digesta viscosity and improved nutrient availability.

\section{KEYWORDS}

Field bean; tannase enzyme; broiler; ME; digestibility

\section{Introduction}

Continuous increase in the demand for soybean meal has led to raising its price, particularly after prohibition of animal protein inclusion in poultry diet by European Union (O'Neill et al., 2012). Soybean is an imported feed ingredient which affects the stability of its price and availability in market (Ravindran et al., 2010; O’Neill et al., 2012). Moreover, large amount of the available soybean meal in the market is produced from genetically modified crops which worries consumers and is not convenience for organic production (Vicenti et al., 2009). These factors have inspired nutritionists to do research on locally grown legumes aiming their optimum and potential seize as an alternative to soybean meal in poultry diet (Crepon, 2006; 
Ravindran et al., 2010). Grain legumes are considered reasonable candidates to soybean meal replacement because of the similarity of their amino acid profiles to those of soybean meal (Wiryawan and Dingle, 1999). The field beans (Vicia faba), unlike the soybean, yields quite satisfactorily in the cooler and shorter growing season of the upper North Temperature Zone. Due to favourable climate conditions, field beans can be produced at a high amount and in wide area in Europe (Crépon et al., 2010).

Field beans are not regularly used in poultry diet formulations because of the presence of antinutritional factors including soluble non-starch polysaccharides (NSP) and tannins (Longstaff and McNab, 1991a,b). Although the beneficial effect of feeding fibre-degrading enzymes to legume-containing diets has been studied (Castanon and Marquardt, 1989; Cowieson et al., 2003), there is a lack of information on the effect of multi enzyme preparation on feeding value of field beans for broilers.

Tannase or tannin acyl-hydrolase (E.C. 3.1.1.20) catalyzes the hydrolysis of ester bonds present in gallotannins, complex tannins and gallic acid esters (Aguilar et al., 2007). Commercially available tannase products generally have other enzyme activities, primarily amylase, pectinase and galactosidase (Boadi and Neufeld, 2001). The application of these tannase-containing enzymes is in food and beverages processes. Little is known of its potential use in poultry feed. Chamorro et al. (2015) found no effect of exogenous tannase on growth performance in chickens fed diet rich in polyphenols, although Abdulla et al. (2016a) showed that dietary tannase can improve feeding value of field beans containing diet for broilers. Although some research has been done (Abdulla et al., 2016b), more information is needed on the effect of multi enzyme preparation (also containing tannin degrading enzymes), on diets with different field bean samples (with different tannin contents) and in comparison with other low-tannin diets. 
The main objective of this experiment, therefore, was to determine the effect of supplementary multi enzyme preparation, containing tannase, xylanase, amylase, pectinase and galactosidase activities on dietary metabolisable energy, nutrient utilisation, ileal digesta viscosity, ileal villus morphometry and gastrointestinal tract development when feeding diets containing field beans with different tannin contents to chickens. The overall feed intake, weight gain and feed conversion efficiency of the birds were also measured.

\section{Materials and methods}

\subsection{Experimental samples}

This report is focused on the nutritional value for broilers of three UK grown field bean samples. The three field bean samples used in the study were produced during 2013 harvest year. All samples were stored in tote bags at ambient air temperatures in a dry store. The stored field bean samples did not experience any freezing temperatures during this period.

\subsection{Proximate analysis of samples}

Dry matter (DM) was determined by drying of samples in a forced draft oven at $105^{\circ} \mathrm{C}$ to a constant weight (AOAC, 2000; method 934.01). Crude protein (CP; 6.25 X N) in samples was determined by dry combustion method (AOAC, 2000; method 990.03) using a Leco (FP-528 N, Leco Corp., St. Joseph, MI). Oil (as ether extract) was extracted with diethyl ether by the ether extraction method (AOAC, 2000; method 945.16) using a Soxtec system (Foss UK Ltd.). The gross energy (GE) value of the field bean samples was determined in a bomb calorimeter (model 6200; Parr Instrument Co., Moline, IL) with benzoic acid used as the standard. Total starch (TS) was determined following the method of Englyst et al. (2000). The non-starch polysaccharides (NSP) content was determined by the method of Englyst et al. (1994), whereby starch is completely dispersed and then hydrolysed enzymatically. The NSP 
101 is isolated by precipitation in $80 \%$ ethanol then hydrolysed by sulphuric acid and the released sugars measured by gas chromatography as their alditol acetate derivatives. The total phenol, total tannin in the control diet, as well as representative samples of studied field bean

104 cultivars, all as tannic acid equivalent, were determined by applying the procedure suggested 105 by Makkar et al. (1993). Whereas condensed tannins, as leucocynidin equivalent, for the same 106 samples were determined by using the assay described by Porter et al. (1985)

\subsection{Diet preparation}

109 Birds were fed one of eight mash diets. A control diet was prepared that had major ingredients 110 of $400.0 \mathrm{~g} / \mathrm{kg}$ wheat and $127.0 \mathrm{~g} / \mathrm{kg}$ soybean meal $(\mathrm{SBM})$, and contained $221 \mathrm{~g} / \mathrm{kg} \mathrm{CP}$ and $11112.83 \mathrm{MJ} / \mathrm{kg}$ metabolisable energy in agreement with breeder's recommendation (Aviagen 112 Ltd., Edinburgh, UK) (Table 1). To reduce nutrient density, the control diet also contained $113119.1 \mathrm{~g} / \mathrm{kg}$ washed sand. Another three diets containing $300 \mathrm{~g} / \mathrm{kg}$ of each of three 114 experimental field bean cultivar samples in replacement for soybean meal and sand were also 115 mixed in order to have AME and CP in a range similar to the control diet (Table 1). Each diet 116 was then split into two batches and one of them was supplemented with an enzyme mixture 117 (Kerry Ingredients and Flavours, Osberstown, Naas, Co. Kildare, Ireland) resulting in eight 118 diets in total. The determined enzyme activities of the enzyme mixture were; tannase or 119 tannin acyl-hydrolase (E.C. 3.1.1.20) 3400 units / kg diet (following the method of Bajpai and

120 Patil (1996) at pH 5.5; determined by Kerry Ingredients and Flavours, Osberstown, Naas, Co.

121 Kildare, Ireland), pectinase (EC 3.2.1.15) 6220 units $/ \mathrm{kg}$ diet (ESC Standard Analytical 122 Method SAM027 at $\mathrm{pH} 4.5$ and $40^{\circ} \mathrm{C}$; determined by Enzyme Services \& Consultancy, 123 Ystrad Mynach, UK); xylanase (EC 3.2.1.8) 6100 units/kg diet (ESC Standard Analytical 124 Method SAM036 at pH 5.3 and $50^{\circ} \mathrm{C}$, using $1.2 \%$ BSA in the extraction; determined by 125 Enzyme Services \& Consultancy, Ystrad Mynach, UK), and there were some additional 
amylase and $\alpha$-galactosidase activities. The enzyme mixture preparation was synthesised by

127 Aspergillus niger. The enzyme was in a liquid form and the reported enzyme activities were obtained after spraying $17 \mathrm{ml} / \mathrm{kg}$ on the top of diets. The dry matter content of nonsupplemented diets was adjusted by spraying of $17 \mathrm{ml}$ water per $\mathrm{kg}$ of diet. After spraying the

130 diets were thoroughly mixed in a horizontal mixer.

131 Diets were free of coccidiostat, antimicrobial growth promoters, prophylactic and other 132 similar additives.

137 University.

138 Male Ross 308 broiler chickens were obtained from a commercial hatchery. During the pre-

139 study period, from day old to 13 days of age, the birds were reared in a single floor pen and

140 fed proprietary wheat-based diet without coccidiostats or antimicrobial growth promoters,

141 prophylactic or other similar additives. At the beginning of the study, at 14 days of age, 144

142 chicks were allocated to 72 small pens with $0.160 \mathrm{~m}^{2}$ solid floors area, two birds in each pen.

143 Room temperature and lighting program followed breeder's recommendations (Aviagen Ltd.,

144 Edinburgh, UK). Feed and water was offered ad libitum to birds throughout the experiment.

145 Each diet was offered to birds in 9 pens in a randomised block design. Information on growth

146 performances was obtained from 14 to $21 \mathrm{~d}$ age. Excreta were collected quantitatively for the

147 last four days of the study from 17 to $21 \mathrm{~d}$ age and feed intake was also recorded. The gross

148 energy, dry matter, nitrogen, and fat of each dried excreta sample and the experimental diets

149 were determined as described for the field bean samples. The AMEn of the diets was

150 calculated as described by Hill and Anderson (1958). The energy conversion ratio (ECR) was 
151 determined as the AMEn ingested to achieve the weight gain over the weight gain for the

152 experimental period. The coefficients of total tract fat digestibility (FD), dry matter (DMR)

153 and nitrogen retention (NR) were determined as the difference between intake and excretion

154 (retention) of the nutrient divided by their respective intake.

155 The energy conversion ratio (ECR) was also determined as the AMEn ingested to achieve the

156 weight gain over the weight gain for the experimental period (Whiting et al., 2016). It

157 describes the relative efficiency of the use of metabolisable energy for growth, rather than

158 heat loss, implicit that a more efficient energy use towards growth is related to a lower ratio.

159 The mucin secretions in excreta were measured using the concentration of the sialic (SA) as a

160 marker, following the periodate-resorcinol method (Jourdian et al., 1971). The method

161 involves conversion of free and glycosidically bound SA to chromogenic substances by

162 treatment with periodic acid followed by resorcinol. The colour of the samples was stabilised

163 by 2-methyl-propan-2-ol, and after centrifugation the absorbance of the supernatant was

164 determined spectrophotometrically at $630 \mathrm{~nm}$ (Spectronic 301; Milton Roy Company,

165 Ivyland, PA). This procedure detects total, free, and glycosidically bound N-acetyl

166 neuraminic (sialic) acid. The endogenous mucin losses in excreta are presented in results and

167 tables as SA. The total SA excretion was obtained by multiplying the SA concentration by the 168 amount of dry excreta collected.

\section{$170 \quad$ 2.5. Digesta viscosity}

171 On the last day of the study, at 21 days of age, the two birds in each pen were weighed and

172 killed by cervical dislocation. The ileal digesta from both birds in each pen were collected and

173 pooled, then centrifuged (10 000g for $2 \mathrm{~min})$. The viscosity of the supernatant (in centipoise

174 (cP) units) was measured using a rotating cone and cup viscometer (model DV - II + LV,

175 Brookfield Engineering Laboratories, USA) as described by Bedford and Classen (1992). 
177 The relative empty weights of GIT segments including proventriculus, gizzard, small intestine 178 and pancreas of each bird were also determined as previously described (Amerah and 179 Ravindran, 2008; Pirgozliev et al., 2016). After that, approximately $5 \mathrm{~cm}$ of the middle part of 180 the jejunum, between the point of bile duct entry and Meckel's diverticulum, of one of the 181 birds was sampled and stored for $2 \mathrm{wk}$ in $10 \%$ formalin-buffered saline. The samples then

182 were embedded in paraffin wax, sectioned at approximately $5 \mu \mathrm{m}$, and 3 gut segments were 183 fixed in each slide. Morphometric measurements were determined on 20 intact well-oriented 184 villus-crypt units for each slide (microscope Microtec, TEC Microscopes LTD, Axbridge, 185 UK; CCD camera Infinity 2, Lumenera Corporation, Ottawa, Canada; Image analysis 186 software, Infinity Analyse - Infinity 2-2 for Windows version 6.5.2, Lumenera Corporation, 187 Ottawa, Canada). The height and the width of the villus, and the crypt depth were determined 188 as previously described (Viveros et al., 2011). The distance between the bottom of the crypt 189 and the outside of the intestine was measured and described as muscle thickness.

\subsection{Statistical procedures}

192 Statistical analyses were performed using the Genstat statistical software package (Genstat $19315^{\text {th }}$ release 3.22 for Windows; IACR, Rothamstead, Hertfordshire, UK). The studied 194 variables were compared statistically by a two way ANOVA using a $2 \times 4$ factorial 195 arrangement of treatments. The main effects were the enzyme supplementation and the four 196 diet formulations (three bean samples and one control diet) giving a total of eight dietary 197 treatments. The differences between the treatments means of the four diet formulations were 198 separated using Duncan's multiple range tests. In addition, an orthogonal comparison contrast test was performed to compare the control diet with the mean of three field bean diets and the 
interaction with exogenous enzymes. In all instances, differences were reported as significant

201 at $\mathrm{P} \leq 0.05$. Tendencies towards significance $(\mathrm{P} \leq 0.1)$ were also reported.

\section{Results}

203

The field bean compositions are summarised in Table 2. The amount of CP was more variable than the ether extract content, and ranged from 244.6 to $304.5 \mathrm{~g} / \mathrm{kg} \mathrm{DM}$, respectively. The total phenols and tannins, as tannic acid equivalent, and condensed tannins, as leucocyanidins, varied between 6.9 to $10.9,6.1$ to 8.3 , and 4.5 to $7.3 \mathrm{~g} / \mathrm{kg} \mathrm{DM}$ for Maris Bead and Sultan, respectively.

The mean total NSP content of the field bean samples was $179.6 \mathrm{~g} / \mathrm{kg} \mathrm{DM}$, comprising 42.5 $\mathrm{g} / \mathrm{kg}$ DM of soluble and $137.1 \mathrm{~g} / \mathrm{kg}$ DM of insoluble NSP, respectively (Table 3). Glucose, galacturonic acid, and arabinose were the main NSP constituent sugars in the field bean samples. The sample of cultivar Sultan had not only the highest tannin content but also contained more soluble NSP compared to the rest of the studied bean samples. The mean starch content of the field bean samples was $444.7 \mathrm{~g} / \mathrm{kg}$ DM, as Wizard cultivar sample had the lowest (424.0 g/kg DM), and Sultan cultivar sample the highest (467.0 g/kg DM) starch content.

There were no mortalities, and the overall weight of the birds was $0.867 \mathrm{~kg}$ (data not in tables), and in agreement with breeder's recommendation (Aviagen Ltd, Edinburgh, UK) (Table 4). Birds fed control diet had higher $(\mathrm{P}<0.001)$ daily FI and WG, compare to the birds fed the rest of the diets. Diet containing cultivar Sultan had low FCE compared to the rest of the diets $(\mathrm{P}<0.001)$. Feeding the enzyme mixture tended $(\mathrm{P}=0.090)$ to reduce daily FI, and improved dietary FCE by $3.5 \%(\mathrm{P}<0.001)$ compared to non-supplemented diets. Orthogonal comparison contrast test showed that birds fed bean containing diets had higher $(\mathrm{P}<0.001) \mathrm{FI}$ and WG compared to the control, but no significant difference was detected for FCE. There were no significant differences in diet formulation $\mathrm{x}$ enzymes interactions. 
The results on dietary available energy and nutrient utilisation are summarised in Table 5 . Sultan containing diets had relatively low metabolisable energy and nutrient utilisation coefficients compared to the rest of the field beans containing diets $(\mathrm{P}<0.001)$. Feeding the enzyme mixture improved dietary AMEn by $0.56 \mathrm{MJ} / \mathrm{kg} \mathrm{DM}(4.1 \%)(\mathrm{P}<0.001)$. Enzyme supplementation also improved $(\mathrm{P}<0.001)$ GE metabolisability, DMR, NR and FD by $3.8 \%$, $3.6 \%, 2.5 \%$ and $9.0 \%$, respectively. The means of the three field bean diets for AMEn, ECR, and DMD were higher $(\mathrm{P}<0.001)$ and NR lower than the control diet. The enzyme mixture improved FD $(\mathrm{P}<0.001)$, although did not affect AMEn:GE ratio. However, the AMEn:GE ratio was changed by dietary formulation $(\mathrm{P}<0.001)$, as diet based on Sultan had higher, although the control diet has lower ratio, compared to the rest. There were no significant differences in diet formulation $\mathrm{x}$ enzymes interactions.

Feeding the experimental diets did not significantly influence the relative weight of the small intestine of the bird (Table 6). Dietary inclusion of beans increased the weight of the PG compared to control fed birds. Birds fed the control diet had smaller $(\mathrm{P}<0.05)$ pancreas compared to the rest. Overall, enzyme mixture supplementation reduced $(\mathrm{P}<0.05)$ the weights of the GIT, PG and the pancreas, but did not influence significantly the small intestine. Contrast test showed that compared to the control, birds fed bean containing diets had increased pancreas $(\mathrm{P}<0.001)$, proventriculus and gizzard $(\mathrm{P}<0.001)$, and total GIT $(\mathrm{P}<0.05)$, although none of the treatments changed weight of the small intestine. There was no significant diet formulation x enzymes interactions.

Dietary enzyme mixture reduced $(\mathrm{P}<0.001)$ viscosity by $46.5 \%$ (Table 7 ). Feeding diets containing Sultan (high in $\mathrm{T})$, reduced $(\mathrm{P}=0.005)$ the concentration of $\mathrm{SA}$ in excreta compared to the rest of the diets. Feeding enzyme however, did not influence SA concentration, but reduced total SA secretion by $9.4 \%(\mathrm{P}<0.001)$. Compared to the mean of the bean diets feeding the control diet increased $(\mathrm{P}<0.05)$ ileal digesta viscosity $(8.31 \mathrm{vs} 6.78 \mathrm{cP})$, and total 
SA $(\mathrm{P}<0.001)$ (329 vs 257). No significant diet formulation $\mathrm{x}$ enzymes interactions were

251 observed.

252 The results on jejunal histomorphological parameters are presented on Table 8. Feeding the 253 control diet increased the muscle thickness of the jejunum compared to feeding Maris Beads 254 and Sultan $(\mathrm{P}=0.038)$. Tannase supplementation tended $(\mathrm{P}=0.061)$ to reduce the muscle 255 thickness of the wall of the jejunum. Villus high and width were not affected $(\mathrm{P}>0.05)$ by the 256 diets and enzyme supplementation. Orthogonal comparison contrast test showed that birds fed 257 bean containing diets had decreased $(\mathrm{P}<0.001)$ jejunal crypt depth compared to the control fed 258 birds (216 vs $240 \mathrm{~nm}$ ) and no diet formulation $\mathrm{x}$ enzymes interactions were observed $259(\mathrm{P}>0.05)$.

\section{Discussion}

The purpose of the experiment reported in this paper was to determine whether tannasecontaining enzyme could be used to improve available energy and nutrient utilisation in field bean containing diets when fed to growing broiler chicks. It was important to evaluate exogenous tannase efficiency using different field bean cultivar samples because of the large variation in the agronomic production and chemical composition of beans available to the animal feed industry.

The sample of bean cultivar Sultan had higher tannin and soluble NSP contents, followed by Wizard and Maris Bead samples. Tannins are hydro soluble and high molecular weight polyphenolic compounds. Tannins have the ability to precipitate macromolecules (such as 270 proteins, cellulose, starch, etc.) and minerals by forming strong complexes (Lekha and 271 Lonsane, 1997). However, compared to Maris Beads and Wizard, Sultan also had a lower metabolisable energy, DMD and a higher ECR most probably due its higher tannins and soluble NSP content. In addition, Sultan had a lower CP content. The lower metabolisable

274 energy and CP content of these diets may have directly affected growth performance. 
275 Reduced mucin losses (measured as SA) in birds fed cultivar Sultan, may be associated with a 276 reduced number of GIT microflora (Pirgozliev et al., 2008). Redondo et al. (2014) also 277 reported reduced bacterial number in excreta when birds were fed tannin containing diets. 278 However, the birds in this study were not under specific microbial challenge, so gut health 279 benefits from dietary tannin contents were not expected.

280 Tannins can form complexes with proteins and bind to enzymes, thus tannins may stimulate 281 pancreatic secretion in a manner analogous to that of proteinase inhibitors from legume seeds 282 (Griffiths, 1980), suggesting an explanation on the increased pancreas size in birds fed field 283 bean containing diets compared to the control fed birds in this study. This is in agreement 284 with previous reports that also found an increased pancreas in broilers fed high-tannin diets 285 (Kubena et al., 1983; Ahmed et al., 1991; Abdulla et al., 2015). Thus suggesting that the 286 increase in pancreas weight of birds fed field beans might have been related to higher dietary 287 tannin contents.

288 The multi enzyme preparation used in this study had not only tannase, but also xylanase, 289 amylase, pectinase and galactosidase activities. The novel aspect of this experiment was to 290 study the effect of the tannase in diets that varied in tannin contents. The control diet was 291 formulated to contain no tannins so no effect of tannase was expected. However, the bean based diets had different tannins contents thus different responses to tannase were expected. A

293 previous report demonstrated that tannase was effective in improving the nutrient availability 294 and performance of broilers fed a diet containing a high tannin field bean sample (Abdulla et 295 al., 2016a, b). No enzyme by diet interaction was observed in the present study and the 296 feeding value of all diets was improved with the same magnitude. Therefore, the potential for 297 tannase alone to improve feeding value of diets was not dependent upon the tannin content 298 and the other enzyme activities, most likely xylanase, may have been more important. 
The most noticeable response to dietary multi enzyme preparation was in reducing digesta

300 viscosity by $46.5 \%$. High digesta viscosity is usually associated with high content of dietary 301 water-soluble NSP (Choct and Annison, 1992). These NSP have a significant capacity to 302 attract and hold water and could directly interact with water molecules to form a large 303 network or mesh-like structure, thereby increasing the viscosity of digesta. Pectinase, tannase 304 and xylanase are known to have the ability to degrade NSP in plants (Zyla et al., 2000; 305 García-Conesa et al., 2001), thus explaining the observed reduction in ileal digesta viscosity. 306 The detrimental impact of high intestinal viscosity on dietary nutrient digestibility and 307 absorption is well documented (Choct and Annison, 1992). The viscous properties have 308 adverse effects on the diffusion and convective transport of pancreatic enzymes, substrates 309 and the end products of the digestion process (Johnson et al., 1984; Isaksson et al., 1982). An 310 increase in intestinal viscosity associated with enhanced bacterial fermentation can also 311 depress fat digestion (Danicke et al. 1999).

312 The enzyme mixture supplementation improved feed efficiency by $3.5 \%$, an increase that is 313 similar to those reported by Abdulla et al. $(2016 \mathrm{a}, \mathrm{b})$ in 21 d-old broilers fed field beans 314 containing diet supplemented with a similar enzyme preparation.

315 The weight of pancreas as a percentage of BW decreased with the enzyme mixture 316 supplementation by $7.1 \%$, a decrease that is similar to the $6.4 \%$ found by Abdulla et al. 317 (2016a) for broilers of similar age when fed a similar enzyme preparation. Feeding 1000 units 318 of xylanase/kg diet also reduced the weight of the pancreas by $10 \%$ (Wu et al., 2004). In 319 addition, Gracia et al. (2003) found a reduced relative weight of pancreas by $17 \%$ after adding 3201720 units of $\alpha$-amylase $/ \mathrm{kg}$ diet. This indicates that secretion of pancreatic enzymes might be 321 affected by the concentration of enzymes and substrates or products of their hydrolysis in the 322 lumen of the small intestine following a feedback mechanism (Kubena et al., 1983). Tannins 323 are able to bind to enzymes, reducing their bioavailability (Singh, 1984), thus the destruction 
324 of tannins by tannase may reduce the secretion of pancreatic enzymes. Mahagna et al. (1995)

325 also reported that secretion of pancreatic amylase and proteases was reduced when chicks

326 were fed diets supplemented with amylase and protease. The combination of fiber degrading

327 enzymes used in this study may also improve the availability of substrates trapped by fibers

328 via disrupting the cell wall matrix (Parkkonen et al., 1997) further reducing the needs of

329 pancreatic enzymes.

330 The weight of the GIT as a percentage of BW decreased with the studied enzyme mixture 331 supplementation by $4.6 \%$, which is similar to the $4.5 \%$ and slightly lower that the $6.3 \%$ found 332 by Gracia et al. (2003) and $\mathrm{Wu}$ et al. (2004), respectively, when feeding $\alpha$-amylase or a 333 mixture of phytase and xylanase to broilers. The weight of the PG was particularly affected 334 and decreased by $7.1 \%$, a decrease that is similar to the $6.1 \%$ reported by Abdulla et al. 335 (2016a) when fed the same enzyme to broilers of similar age. Wu et al. (2004) also reported a 336 reduced weight of the PG by $7.4 \%$ when feeding a mixture of phytase and xylanase to 337 broilers. A similar trend was observed by Gracia et al. (2003) after feeding $\alpha$-amylase to 338 broilers at similar age. The reduction in GIT in birds given enzyme mixture containing diets 339 paralleled the reduction in digesta viscosity and intestinal muscle thickness and the 340 improvement in metabolisable energy, nutrient utilisation and feed efficiency in agreement 341 with Abdulla et al. (2016a). In general, if the efficiency of digestion is consistently 342 suboptimal, whether due to ingredient quality, microbial interaction of anti-nutritive factors, 343 the GIT responds by increasing in both size (surface area) and digestive enzyme output 344 (Bedford, 2006). Birds fed multi enzyme mixture also secreted less mucin thus supporting the 345 view that the reduction in GIT in this experiment might have been related to enhanced 346 efficiency of digestion. 
347 Jejunal morphometry is not always the key factor associated with better function and 348 production in poultry (Wu et al., 2004; Pirgozliev et al., 2010), thus the lack of correlation 349 with productive performance is not surprising.

351 5. Conclusions

352 The results from this study show that a commercial enzyme preparation containing tannase, 353 pectinase and xylanase activities proved to be a highly effective in improving dietary 354 available energy, nutrient utilisation, and feed efficiency when fed to chickens. The results 355 also showed that the feeding value of field beans with different tannin contents may vary 356 when fed to broilers although there were no interactions with the enzyme preparation used in 357 the study.

\section{Acknowledgements}

360 We thank Richard James, Rose Crocker, Amjad Ali, Kevin Jones and Waseem Mirza for their 361 technical support. We also thank Kerry Ingredients and Flavours (Ireland) for providing us 362 with the enzyme and Askew \& Barrett (Pulses) Ltd which donated the field bean samples for 363 this study.

\section{Disclosure statement}

366 No potential conflict of interest was reported by the authors.

\section{Funding}

369 This experiment is a part of a PhD project funded by the Ministry of Higher Education and

370 Scientific Research - Kurdistan Regional Government - Iraq. 


\section{References}

[AOAC] Association of Official Analytical Chemists. 2000. Official methods of analysis of 383 AOAC. 17th ed. Vol. II. Gaithersburg (MD): Association of Official Analytical Chemists.

Abdulla J, Pirgozliev V, Rose SP, Mackenzie AM. 2015. Feeding quality of field beans for broiler chickens. Brit Poult Abstr. 11:2-3.

Abdulla J, Rose SP, Mackenzie AM, Mirza W, Pirgozliev V. 2016a. Exogenous tannase improves feeding value of a diet containing field beans (Vicia faba) when fed to broilers. Brit Poult Sci. 57:246-250.

Abdulla J, Rose SP, Mackenzie AM, Ivanova SG, Staykova GP, Pirgozliev V. 2016 b.

390 Nutritional value of raw and micronised field beans (Vicia faba L. var. minor) with and 391 without enzyme supplementation containing tannase for growing chickens, Archives of 392 Animal Nutrition 70: (5) 350-363.

Aguilar CN, Rodr'1guez R, Gutierrez-Sanchez G, Augur C, Favela-Torres E, Prado-

394 Barrag'an LA, Ram'ırez-Coronel A, Contreras-Esquivel JC. 2007. Microbial Tannases: 395 Advances and Perspectives. Appl Microbiol Biotechnol. 76:47-59. 
Ahmed AE, Smithard R, Ellis M. 1991. Activities of enzymes of the pancreas, and the lumen and mucosa of the small intestine in growing broiler cockerels fed on tannin containing diets. Brit J Nutr. 65:189-197.

Amerah AM, Ravindran V. 2008. Influence of method of whole-wheat feeding on the performance, digestive tract development and carcass traits of broiler chickens. Anim Feed Sci Technol. 147:326-339.

Bajpai B, Patil S. 1996. Tannin acyl hydrolase ( EC 3. 1. 1 .20) activity of Aspergillus, 403 Penicillium, Fusarium and Trichoderma. World J Microbiol Biotechnol. 12:217-220.

Bedford MR, Classen HL. 1992. Reduction of intestinal viscosity through manipulation of 405 dietary rye and pentosanase concentration is effected through changes in the carbohydrate composition of the intestinal aqueous phase and results in improved growth rate and food

Bedford MR. 2006. Effect of non-starch polysaccharidases on avian gastrointestinal function. conversion efficiency of broiler chicks. J Nutr. 122:560-569.

411 Boadi DK, Neufeld RJ. 2001. Encapsulation of tannase for the hydrolysis of tea tannins. $412 \quad$ Enzyme Microb Technol. 28:590-595.

413 Castanon JL, Marquardt RR. 1989. Effect of enzyme addition, autoclave treatment and 414 fermenting on the nutritive value of field beans (Vicia faba L.). Anim Feed Sci Technol. $415 \quad 26: 71-79$. 
416 Chamorro S, Viveros A, Rebolé A, Rica BD, Arija I, Brenes A. 2015. Influence of dietary 417 enzyme addition on polyphenol utilization and meat lipid oxidation of chicks fed grape 418 pomace. Food Res Intern. 73:197-203.

419 Choct M, Annison G. 1992. Anti-nutritive activity of the wheat pentosans in broiler chicken: 420 role of viscosity and gut microflora. Brit Poult Sci. 33:821-834.

421 Cowieson AJ, Acamovic T, Bedford M R. 2003. Supplementation of diets containing pea 422 meal with exogenous enzymes: effects on weight gain, feed conversion, nutrient digestibility and gross morphology of the gastrointestinal tract of growing broiler chicks. Brit Poult Sci. 44:427-437.

Crépon K, Marget P, Peyronnet C, Carrouée B, Arese P, Duc G. 2010. Nutritional value of 426 faba bean (Vicia faba L.) seeds for feed and food. Field Crops Res. 115: 329-339.

Crepon K. 2006. Nutritional value of legumes (pea and faba bean) and economics of their use. In: Garnsworthy PC Wiseman J, editors. Recent Advances in Animal Nutrition. Nottingham: Nottingham University press; p. 332-366.

Dänicke S, Simon O, Jeroch H, Keller K, Gläser K, Kluge H, Bedford MR. 1999. Effects of dietary fat type, pentosan level and xylanase supplementation on digestibility of nutrients and metabolizability of energy in male broilers. Arch Tierernahr. 52:245-61.

Englyst HN, Quigley ME, Hudson GJ. 1994. Determination of dietary fibre as non-starch 434 polysaccharides with gas-liquid chromatographic, high-performance liquid 435 chromatographic or spectrophotometric measurement of constituent sugars. Analyst. $436 \quad 119: 1497-1509$ 
Englyst KN, Hudson GJ, Englyst HN. 2000. Starch analysis in food. In: Meyers RA, editor. Encyclopaedia of analytical chemistry. Chichester: John Wiley and Sons; p. 4246-4262.

Garc1'a-Conesa MT, Østergaard P, Kauppinen S, Williamson G. 2001. Hydrolysis of diethyl diferulates by a tannase from Aspergillus oryzae. Carbohydrate Polymers. 44:319-324.

GenStat 15 th release 3.22 for Windows; IACR, Rothamstead, Hertfordshire.

Gracia MI, Aranı'bar M, La'zaro R, Medel P, Mateos GG. 2003. $\alpha$-Amylase supplementation of broiler diets based on corn. Poult Sci. 82:436-442.

Griffiths DW. 1980. The inhibition of digestive enzymes by polyphenolic compounds. In: Friedman M, editor. Nutritional and Toxicological Significance of Enzyme Inhibitors in Foods. New York: Plenum Press; p. 509-516.

Hill FW, Anderson DL. 1958. Comparison of metabolisable energy and productive energy determinations with growing chicks. J Nutr. 64:587-603.

Isaksson G, Lundquist I, Ihse I. 1982. Effect of dietary fiber on pancreatic enzyme activity in vitro: the importance of viscosity, $\mathrm{pH}$, ionic strength, absorption and time of incubation. Gastroenterology. 82:918-924.

Johnson IT, Gee JM, Mahoney RR. 1984. Effect of dietary supplements of guar gum and cellulose on intestinal cell proliferation, enzyme levels and sugar transport in the rat. Brit $\mathbf{J}$ Nutr. 52:477-487.

Jourdian GW, Dean L, Roseman S. 1971. The sialic acids XI. A periodate-resorcinol method for the quantitative estimation of free sialic acids and their glycosides. J Biol Chem. $246: 430-435$. 
458 Kubena LF, Phillips TD, Creger CR, Witzel DA, Heidelbaugh ND. 1983. Toxicity of 459 ochratoxin A and tannic acid to growing chicks. Poult Sci. 62:1786-1792.

460 Lekha PK, Lonsane BK. 1997. Production and application of tannin acyl hydrolase: state of 461 the art. Adv Appl Microbiol. 44:216-260

462 Longstaff M, McNab JM. 1991a. The inhibitory effects of hull polysaccharides and tannins of 463 field beans (Vicia faba L.) on the digestion of amino acids, starch and lipid and on 464 digestive enzyme activities in young chicks. Brit J Nutr. 65:199-216.

465 Longstaff MA, McNab JM. 1991b. The effect of concentration of tannin-rich bean hulls 466 (Vicia faba L.) on activities of lipase (EC 3.1. 1.3) and $\alpha$-amylase (EC 3.2. 1.1) in digesta 467 and pancreas and on the digestion of lipid and starch by young chicks. Brit J Nutr. 66:139$468 \quad 147$.

469 Mahagna M, Nir I, Larbier M, Nitsan Z. 1995. Effect of age and exogenous amylase and 470 protease on development of the digestive tract, pancreatic enzyme activities and 471 digestibility of nutrients in young meat-type chicks. Reproduction Nutr Development. $472 \quad 35: 201-212$.

473 Makkar HP, Blümmel M, Borowy NK, Becker K. 1993. Gravimetric determination of tannins 474 and their correlations with chemical and protein precipitation methods. J Sci Food Agri. $475 \quad 61: 161-165$.

476 O’Neill HM, Rademacher M, Mueller-Harvey I, Stringano E, Kightley S, Wiseman J. 2012. 477 Standardised ileal digestibility of crude protein and amino acids of UK grown peas and 478 faba beans by broilers. Anim Feed Sci Technol. 175:158-167. 
Parkkonen T, Tervilä-Wilo A, Hopeakoski-Nurminen M, Morgan A, Poutanen K, Autio K. 1997. Changes in wheat micro structure following in vitro digestion. Acta Agriculturae Scandinavica B-Plant Soil Sci. 47:43-47.

Pirgozliev V, Mirza MW, Rose SP. 2016. Does the effect of pelleting depend on the wheat sample?. Animal. 10:571-577.

Pirgozliev V, Murphy TC, Owens B, George J, McCann MEE. 2008. Fumaric and sorbic acid as additives in broiler feed. Res Vet Sci. 84:387-394.

Pirgozliev V, Rose SP, Bedford MR. 2010. The effect of amylose:amylopectin ratio in dietary starch on growth performances and gut morphology in broiler chickens. Arch Geflugelkunde. 74:21-29.

Porter LJ, Hrstich LN, Chan BG. 1985. The conversion of procyanidins and prodelphinidins to cyanidin and delphinidin. Phytochemistry. 25:223-230.

Ravindran G, Nalle CL, Molan A, Ravindran V. 2010. Nutritional and biochemical assessment of field peas (Pisum sativum L.) as a protein source in poultry diets. J Poult Sci. $47: 48-52$

Redondo LM, Chacana PA, Dominguez JE, Miyakawa MEF. 2014. Perspectives in the use of tannins as alternative to antimicrobial growth promoter factors in poultry. Frontiers in Microbiol. 5:122-128.

Singh U. 1984. The inhibition of digestive enzymes by polyphenols of chickpea (Cicer Arietinum L.) and pigeonpea (Cajanus Cajan (L.) Millsp.). Nutr Reports Int. 29:745-753. 
Vicenti A, Toteda F, Di Turi L, Cocca C, Perrucci M, Melodia L, Ragni M. 2009. Use of sweet lupin (Lupinus albus L. var. Multitalia) in feeding for Podolian young bulls and influence on productive performances and meat quality traits. Meat Sci. 82:247-251.

Viveros A, Chamorro S, Pizarro M, Arija I, Centeno C, Brenes A. 2011. Effects of dietary polyphenol-rich grape products on intestinal microflora and gut morphology in broiler chicks. Poult Scie. 90:566-578.

Whiting IM, Pirgozliev V, Rose SP, Wilson J, Amerah AM, Ivanova SG, Staykova GP, Oluwatosin OO, Oso AO. 2016. Nutrient availability of different batches of wheat distillers dried grains with solubles with and without exogenous enzymes for broiler chickens. Poult Sci. -in press.

Wiryawan KG, Dingle JG. 1999. Recent research on improving the quality of grain legumes for chicken growth. Anim Feed Sci Technol. 76:185-193.

Wu YB, Ravindran V, Thomas DG, Birtles MJ, Hendriks WH. 2004. Influence of phytase and xylanase, individually or in combination, on performance, apparent metabolisable energy, digestive tract measurements and gut morphology in broilers fed wheat-based diets containing adequate level of phosphorus. Brit Poult Sci. 45:76-84.

Zyla K, Wikiera A, Koreleski J, Swiatkiewicz S, Piironen J, Ledoux DR. 2000. Comparison of the efficacies of a novel Aspergillus niger mycelium with separate and combined effectiveness of phytase, acid phosphatase, and pectinase in dephosphorylation of wheatbased feeds fed to growing broilers. Poult Sci. 79:1434-1443.

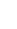


Table 1. Ingredient composition $(\mathrm{g} / \mathrm{kg}$, as-fed) of the experimental broiler chicken balancer and control diet

521 formulations

\begin{tabular}{|c|c|c|c|c|}
\hline & Control & Maris Bead & Sultan & Wizard \\
\hline Wheat & 400.0 & 404.2 & 404.2 & 404.2 \\
\hline Bean (Maris Bead) & - & 300.0 & - & - \\
\hline Bean (Sultan) & - & - & 300.0 & - \\
\hline Bean (Wizard) & - & - & - & 300.0 \\
\hline $\operatorname{SBM}(\mathrm{CP}=48 \%)$ & 190.4 & 27.0 & 27.0 & 27.0 \\
\hline Full fat soya meal & 127.0 & 127.5 & 127.5 & 127.5 \\
\hline Maize gluten meal & 35.0 & 35.0 & 35.0 & 35.0 \\
\hline Washed sand & 119.1 & - & - & - \\
\hline Soya oil & 82.5 & 65.0 & 65.0 & 65.0 \\
\hline Lysine & 6.0 & 2.3 & 2.3 & 2.3 \\
\hline Methionine & 6.8 & 5.8 & 5.8 & 5.8 \\
\hline Threonine & 2.4 & 2.4 & 2.4 & 2.4 \\
\hline Monocalcium phosphate & 10.0 & 10.0 & 10.0 & 10.0 \\
\hline Limestone & 14.0 & 14.0 & 14.0 & 14.0 \\
\hline Salt & 2.8 & 2.8 & 2.8 & 2.8 \\
\hline Vitamin/mineral premix & 4.0 & 4.0 & 4.0 & 4.0 \\
\hline Total & 1000 & 1000 & 1000 & 1000 \\
\hline \multicolumn{5}{|l|}{ Calculated values } \\
\hline $\mathrm{ME}(\mathrm{MJ} / \mathrm{kg})$ & 12.83 & 13.12 & 12.65 & 13.15 \\
\hline Crude protein $(\mathrm{g} / \mathrm{kg})$ & 221 & 217 & 201 & 216 \\
\hline Ether extract (g/kg) & 113 & 97 & 97 & 97 \\
\hline $\mathrm{Ca}(\mathrm{g} / \mathrm{kg})$ & 7.9 & 8.1 & 8.2 & 8.2 \\
\hline Av P (g/kg) & 4.4 & 4.4 & 4.4 & 4.4 \\
\hline Total lysine (g/kg) & 15.1 & 12.4 & 11.8 & 12.7 \\
\hline Total methionine + cysteine $(\mathrm{g} / \mathrm{kg})$ & 13.5 & 8.6 & 8.4 & 8.6 \\
\hline \multicolumn{5}{|l|}{ Analysed values (as-fed) } \\
\hline $\mathrm{DM}(\mathrm{g} / \mathrm{kg})$ & 855 & 877 & 876 & 876 \\
\hline GE (MJ/kg) & 16.21 & 17.57 & 17.52 & 17.60 \\
\hline $\mathrm{CP}(\mathrm{g} / \mathrm{kg})$ & 197 & 198 & 183 & 197 \\
\hline Ether extract (g/kg) & 112 & 95 & 95 & 95 \\
\hline Total phenols ${ }^{\mathrm{a}}$ & 1.312 & 2.770 & 3.791 & 3.084 \\
\hline Tannins $^{\mathrm{a}}$ & 0.452 & 1.991 & 2.550 & 2.159 \\
\hline Condensed tannins $^{\mathrm{b}}$ & 0.00 & 1.17 & 1.86 & 1.53 \\
\hline
\end{tabular}

* Vitamin and mineral premix provided (units · $\mathrm{kg}-1$ feed): $\mu \mathrm{g}$ : retinol 2160, cholecalciferol 75 ; mg: alpha-

524 tocopherol 25 , menadione 1.5 , riboflavin 5 , pantotenic acid 8 , cyanocobalamin 0.01 , pyridoxine 1.5 , thiamine 5251.5 , folic acid 0.5, niacin 30, biotin 0.06, I 0.8, Cu 10, Fe 80, Se 0.3, Mn 80, Zn 80. Diets were not supplemented 526 with coccidiostat. The vitamin and mineral premix was supplied by Target Feeds Ltd, Whitchurch, UK.

$527{ }^{a}$ As tannic acid equivalent

$528 \quad$ b As leucocyanidin equivalent 
532 Table 2. Chemical composition of the experimental field bean cultivar samples (DM basis)

\begin{tabular}{lccc}
\hline & \multicolumn{3}{c}{ Field beans } \\
\cline { 2 - 4 } & Maris Bead & Sultan & Wizard \\
\hline Dry matter $(\mathrm{g} / \mathrm{kg})$ & 858 & 856 & 855 \\
Ether extract $(\mathrm{g} / \mathrm{kg})$ & 10.5 & 11.7 & 10.5 \\
Crude protein $(\mathrm{g} / \mathrm{kg})$ & 304.5 & 244.6 & 299.7 \\
Gross energy $(\mathrm{MJ} / \mathrm{kg})$ & 18.41 & 18.27 & 18.59 \\
Total phenols $(\mathrm{g} / \mathrm{kg})^{\mathrm{a}}$ & 6.9 & 10.9 & 8.1 \\
Tannins $(\mathrm{g} / \mathrm{kg})^{\mathrm{a}}$ & 6.1 & 8.3 & 6.8 \\
Condensed tannins $(\mathrm{g} / \mathrm{kg})^{\mathrm{b}}$ & 4.5 & 7.3 & 6.0 \\
\hline
\end{tabular}

533

534 a As tannic acid equivalent

$535 \quad \mathrm{~b}$ As leucocyanidin equivalent

536 Note: All data are the results of a chemical analysis conducted in triplicate.

537

538

539

540

541

542

543

544

545

546

547

548

549 
Table 3. Carbohydrate contents $(\mathrm{g} / \mathrm{kg} \mathrm{DM})$ of the studied field bean cultivars

\begin{tabular}{|c|c|c|c|c|c|c|c|c|c|c|c|c|}
\hline \multirow[t]{2}{*}{ Bean cultivar } & \multirow[t]{2}{*}{ Fraction } & \multicolumn{9}{|c|}{ NSP constituent sugars } & \multirow[b]{2}{*}{ Total } & \multirow[b]{2}{*}{ Total starch } \\
\hline & & rha & fuc & ara & xyl & $\operatorname{man}$ & gal & glu & GlcA & GalA & & \\
\hline \multirow{3}{*}{ Maris Bead } & Soluble sugar & 0.9 & 0.7 & 7.6 & 2.8 & 1.4 & 4.9 & 1.5 & 0.0 & 10.1 & 30.0 & \\
\hline & Insoluble sugar & 0.2 & 0.2 & 12.5 & 11.4 & 4.2 & 3.3 & 80.9 & 0.0 & 12.7 & 125.5 & \\
\hline & Total sugar & 1.1 & 0.9 & 20.1 & 14.3 & 5.6 & 8.2 & 82.3 & 0.0 & 22.8 & 155.4 & 443 \\
\hline \multirow{3}{*}{ Sultan } & Soluble sugar & 1.0 & 0.4 & 9.7 & 3.7 & 2.1 & 5.4 & 15.4 & 0.0 & 17.1 & 54.8 & \\
\hline & Insoluble sugar & 0.0 & 0.5 & 11.4 & 8.2 & 4.6 & 3.1 & 96.1 & 0.0 & 11.6 & 135.4 & \\
\hline & Total sugar & 1.0 & 0.9 & 21.0 & 11.9 & 6.6 & 8.5 & 111.5 & 0.0 & 28.7 & 190.1 & 467 \\
\hline \multirow{3}{*}{ Wizard } & Soluble sugar & 0.8 & 0.5 & 11.1 & 3.6 & 2.0 & 5.6 & 4.9 & 0.0 & 14.2 & 42.8 & \\
\hline & Insoluble sugar & 0.3 & 0.4 & 11.8 & 15.8 & 5.0 & 3.2 & 101.8 & 0.0 & 12.1 & 150.4 & \\
\hline & Total sugar & 1.2 & 0.9 & 23.0 & 19.5 & 6.9 & 8.8 & 106.7 & 0.0 & 26.3 & 193.2 & 424 \\
\hline
\end{tabular}

551

Note: All data are the results of a chemical analysis conducted in duplicate. 
562 Table 4. Daily feed intake (FI), daily weight gain (WG) and feed conversion efficiency (FCE) ratio of broiler 563 chickens fed the experimental diets.

\begin{tabular}{lccc}
\hline Treatment factor & $\begin{array}{c}\mathrm{FI} \\
(\mathrm{g} \mathrm{DM} / \mathrm{b} / \mathrm{d})\end{array}$ & $\begin{array}{c}\mathrm{WG} \\
(\mathrm{g} / \mathrm{b} / \mathrm{d})\end{array}$ & $\begin{array}{c}\text { FCE } \\
(\mathrm{g}: \mathrm{g})\end{array}$ \\
\hline Diet formulation & & & \\
Bean (Maris Bead) & $75.8^{\mathrm{a}}$ & $62.9^{\mathrm{b}}$ & $0.829^{\mathrm{b}}$ \\
Bean (Wizard) & $75.7^{\mathrm{a}}$ & $61.4^{\mathrm{ab}}$ & $0.811^{\mathrm{b}}$ \\
Bean (Sultan) & $76.6^{\mathrm{a}}$ & $58.5^{\mathrm{a}}$ & $0.764^{\mathrm{a}}$ \\
Control (no beans) & $82.9^{\mathrm{b}}$ & $67.3^{\mathrm{c}}$ & $0.812^{\mathrm{b}}$ \\
SEM & 1.11 & 1.11 & 0.0065 \\
Enzymes & & & \\
- & 78.8 & 62.3 & 0.790 \\
+ & 76.7 & 62.8 & 0.818 \\
SEM & 0.79 & 0.78 & 0.0046 \\
p-Value & & & \\
Diet formulation & $<0.001$ & $<0.001$ & $<0.001$ \\
Enzymes & 0.069 & 0.649 & $<0.001$ \\
Diet x Enzymes interactions* & 0.921 & 0.890 & 0.293 \\
\hline
\end{tabular}

565 Notes: SEM, Standard error of the mean; p-Value, Comparison of the mean of dietary sources.

566 Each mean represents values from 9 replicate pens of 2 chicks each; Bird performance was determined from 13

567 to $21 \mathrm{~d}$ age; There is statistically significant difference between treatments when $P \leq 0.05$.

568 a,b,c Values within a column with different superscripts differ significantly at $P \leq 0.05$.

$569 *$ As there were no significant $(\mathrm{P}>0.05)$ diet formulation $\mathrm{x}$ enzymes interactions only the main treatment factor

570 effects are presented in the table. 
585 Table 5. Dietary available energy and nutrient retention coefficients

\begin{tabular}{lcccccc}
\hline Treatment factor & & & \multicolumn{5}{c}{ Retention coefficients } \\
\cline { 5 - 8 } & $\begin{array}{c}\text { AMEn } \\
\text { (MJ/kg DM) }\end{array}$ & ECR & GE & DM & NR & FD \\
\hline Diet formulation & & & & & & \\
Bean (Maris Bead) & $14.10^{\mathrm{c}}$ & $17.01^{\mathrm{b}}$ & $0.699^{\mathrm{bc}}$ & $0.669^{\mathrm{c}}$ & $0.649^{\mathrm{b}}$ & 0.744 \\
Bean (Wizard) & $14.16^{\mathrm{c}}$ & $17.46^{\mathrm{b}}$ & $0.705^{\mathrm{c}}$ & $0.677^{\mathrm{c}}$ & $0.657^{\mathrm{bc}}$ & 0.757 \\
Bean (Sultan) & $13.74^{\mathrm{b}}$ & $18.00^{\mathrm{c}}$ & $0.680^{\mathrm{a}}$ & $0.644^{\mathrm{b}}$ & $0.634^{\mathrm{a}}$ & 0.718 \\
Control (no beans) & $13.12^{\mathrm{a}}$ & $16.21^{\mathrm{a}}$ & $0.688^{\mathrm{ab}}$ & $0.612^{\mathrm{a}}$ & $0.660^{\mathrm{c}}$ & 0.750 \\
SEM & 0.089 & 0.176 & 0.0045 & 0.0035 & 0.0031 & 0.0148 \\
& & & & & & \\
Enzymes & & & & & & \\
- & 13.50 & 17.11 & 0.680 & 0.639 & 0.642 & 0.710 \\
+ & 14.06 & 17.23 & 0.706 & 0.662 & 0.658 & 0.774 \\
SEM & 0.063 & 0.124 & 0.0032 & 0.0025 & 0.0022 & 0.0105 \\
& & & & & & \\
p-Value & & & & & & \\
Diet formulation & $<0.001$ & $<0.001$ & 0.001 & $<0.001$ & $<0.001$ & 0.278 \\
Enzymes & $<0.001$ & 0.501 & $<0.001$ & $<0.001$ & $<0.001$ & $<0.001$ \\
Diet x Enzymes interactions * & 0.917 & 0.331 & 0.771 & 0.739 & 0.645 & 0.949 \\
\hline
\end{tabular}

586

587 Notes: AMEn, N-corrected apparent metabolisable energy; GE, gross energy; ECR, energy conversion ratio;

588 DM, Coefficient of total tract dry matter retention; NR, Coefficient of total tract nitrogen retention; FD,

589 Coefficient of total tract fat digestibility; SEM, Standard error of the mean; p-Value, Comparison of the mean of

590 dietary sources.

591 Each mean represents values from 9 replicate pens of 2 chicks each; Dietary DMR, NR and FD were determined

592 between 17 and $21 \mathrm{~d}$ age; There is statistically significant difference between treatments when $P \leq 0.05$.

$593 \quad$ a,b,c $V a l u e s$ within a column with different superscripts differ significantly at $P \leq 0.05$.

$594 *$ As there were no significant $(\mathrm{P}>0.05)$ diet formulation $\mathrm{x}$ enzymes interactions only the main treatment factor

595 effects are presented in the table.

596

597

598

599

600

601

602

603

604

605

606 
Table 6. Gastrointestinal tract development responses to the experimental diets

\begin{tabular}{lcccc}
\hline Treatment factor & $\begin{array}{c}\text { Total GIT } \\
(\%)\end{array}$ & $\begin{array}{c}\text { PG } \\
(\%)\end{array}$ & $\begin{array}{c}\text { Pancreas } \\
(\%)\end{array}$ & $\begin{array}{c}\text { SI } \\
(\%)\end{array}$ \\
\hline Diet formulation & & & & \\
Bean (Maris Bead) & $7.75^{\mathrm{ab}}$ & $2.75^{\mathrm{a}}$ & $0.42^{\mathrm{a}}$ & 4.59 \\
Bean (Wizard) & $7.65^{\mathrm{b}}$ & $2.55^{\mathrm{b}}$ & $0.42^{\mathrm{a}}$ & 4.68 \\
Bean (Sultan) & $7.96^{\mathrm{b}}$ & $2.76^{\mathrm{a}}$ & $0.44^{\mathrm{a}}$ & 4.76 \\
Control (no beans) & $7.41^{\mathrm{a}}$ & $2.33^{\mathrm{c}}$ & $0.36^{\mathrm{b}}$ & 4.72 \\
SEM & 0.126 & 0.058 & 0.01174 & 0.1070 \\
& & & & \\
Enzymes & & & & \\
- & 7.87 & 2.69 & 0.42 & 4.76 \\
+ & 7.51 & 2.50 & 0.39 & 4.62 \\
SEM & 0.089 & 0.041 & 0.0083 & 0.076 \\
& & & & \\
p-Value & & & & \\
Diet formulation & & & & \\
Enzymes & 0.025 & $<0.001$ & $<0.001$ & 0.713 \\
Diet x Enzymes interactions * & 0.007 & 0.002 & 0.018 & 0.192 \\
& 0.764 & 0.194 & 0.612 & 0.617 \\
\hline
\end{tabular}

608

609 Notes: GIT (\%), Gastrointestinal tract as a proportion of the body weight; PG (\%), Proventriculus and gizzard as 610 a proportion of the body weight; SI (\%), Small intestine as a proportion of the body weight; SEM, Standard error 611 of the mean; p-Value, Comparison of the mean of dietary sources;

612 Each mean represents values from 9 replicate pens; Gastrointestinal tract development were determined at $21 \mathrm{~d}$

613 old using heavier bird in each pen; There is statistically significant difference between treatments when $P \leq 0.05$.

614 a,b,c Values within a column with different superscripts differ significantly at $\mathrm{P} \leq 0.05$.

$615 *$ As there were no significant $(\mathrm{P}>0.05)$ diet formulation $\mathrm{x}$ enzymes interactions only the main treatment factor 616 effects are presented in the table.

617

618

619

620

621

622

623

624

625

626 
627 Table 7. Ileal digesta viscosity and sialic acid secretion responses to the experimental diets

\begin{tabular}{lccc}
\hline Treatment factor & $\mathrm{cPa}$ & $\mathrm{SA}(\mu \mathrm{g} / \mathrm{g} \mathrm{DM})$ & Total SA $(\mu \mathrm{g})$ \\
\hline Diet formulation & & & \\
Bean (Maris Bead) & 7.12 & $1.01^{\mathrm{b}}$ & $256^{\mathrm{a}}$ \\
Bean (Wizard) & 6.82 & $1.03^{\mathrm{b}}$ & $255^{\mathrm{a}}$ \\
Bean (Sultan) & 6.40 & $0.94^{\mathrm{a}}$ & $259^{\mathrm{a}}$ \\
Control (no beans) & 8.31 & $1.03^{\mathrm{b}}$ & $329^{\mathrm{b}}$ \\
SEM & 0.548 & 0.020 & 7.8 \\
& & & \\
Enzymes & & & \\
- & 9.33 & 1.01 & 288 \\
+ & 4.99 & 1.00 & 261 \\
SEM & 0.387 & 0.014 & 5.5 \\
& & & \\
p-Value & & & $<0.001$ \\
Diet formulation & 0.096 & 0.005 & $<0.001$ \\
Enzymes & $<0.001$ & 0.628 & 0.293 \\
Diet x Enzymes interactions * & 0.940 & 0.193 & \\
\hline
\end{tabular}

628

629 Notes: cPa, Dynamic ileal digesta viscosity; SA ( $\mu \mathrm{g} / \mathrm{g} \mathrm{DM})$, Sialic acid concentration in excreta; Total SA ( $\mu \mathrm{g})$,

630 Total sialic acid excretion; SEM, Standard error of the mean; p-Value, Comparison of the mean of dietary

631 sources

632 Each mean represents values from 9 replicate pens; Viscosity of the supernatant (in centipoise (cPa) units) was

633 determined at $21 \mathrm{~d}$ old; There is statistically significant difference between treatments when $P \leq 0.05$. ${ }^{\text {a,b}}$ Values

634 within a column with different superscripts differ significantly at $P \leq 0.05$.

$635 *$ As there were no significant $(\mathrm{P}>0.05)$ diet formulation $\mathrm{x}$ enzymes interactions only the main treatment factor

636 effects are presented in the table.

637

638

639

640

641

642

643

644

645 
646 Table 8. Jejunum histomorphological variables $(\mu \mathrm{m})$ responses to the experimental diets

\begin{tabular}{lcccc}
\hline \multicolumn{1}{c}{ Treatment factor } & Muscle thickness & Crypt depth & Villus high & Villus width \\
\hline Diet formulation & & & & \\
Bean (Maris Bead) & $181^{\mathrm{a}}$ & 217 & 1045 & 185 \\
Bean (Wizard) & $197^{\mathrm{ab}}$ & 210 & 978 & 170 \\
Bean (Sultan) & $180^{\mathrm{a}}$ & 222 & 999 & 196 \\
Control (no beans) & $201^{\mathrm{b}}$ & 240 & 1025 & 185 \\
SEM & 6.3 & 8.3 & 33.8 & 10.7 \\
& & & & \\
Enzymes & & & & \\
- & 196 & 222 & 1015 & 180 \\
+ & 184 & 222 & 1008 & 188 \\
SEM & 4.4 & 5.9 & 23.9 & 7.5 \\
& & & & \\
p-Value & & & & 0.403 \\
Diet formulation & 0.038 & 0.072 & 0.532 & 0.435 \\
Enzymes & 0.061 & 0.979 & 0.856 & 0.765 \\
Diet x Enzymes interactions * & 0.525 & 0.573 & 0.447 & \\
\hline
\end{tabular}

647

648 Notes: SEM, Standard error of the mean; p-Value, Comparison of the mean of dietary sources.

649 Each mean represents values from 9 replicate pens and was determined at $21 \mathrm{~d}$ old;

650 There is statistically significant difference between treatments when $P \leq 0.05$.

651 a,b Values within a column with different superscripts differ significantly at $P \leq 0.05$.

$652 *$ As there were no significant $(\mathrm{P}>0.05)$ diet formulation $\mathrm{x}$ enzymes interactions only the main treatment factor

653 effects are presented in the table. 